\title{
An Update of Oral Therapies Used for Children and Adolescent of Autism Spectrum Disorder (ASD) and Recommended Prosthodontic Guidelines
}

\author{
Sachin Chaware ${ }^{1 *}$, Surekha Dubey Godbole ${ }^{2}$ and Vrushali Thakare ${ }^{3}$ \\ ${ }^{1}$ Professor and PG Teacher, Department of Prosthodontics, MGV Dental College, Nashik, India \\ ${ }^{2}$ Professor and PG Teacher, Department of Prosthodontics, Sharad Pawar Dental College, \\ India \\ ${ }^{3}$ Reader, Department of Public Health Dentistry, MGV Dental College, Nashik, India \\ *Corresponding Author: Sachin Chaware, Professor and PG Teacher, Department \\ of Prosthodontics, MGV Dental College, Nashik, India.
}

DOI: $10.31080 /$ ASDS.2020.04.0990

Received: October 29, 2020

Published: November 27, 2020

(C) All rights are reserved by Sachin

\begin{abstract}
Autism spectrum disorder (ASD) is the most prevalent Neurodevelopmental condition of unknown etiology. The integration of sensory difficulties with ASD affects the day to day routine activities and shows much dependence on parents or caretakers of ASD children and adolescents. The most significant oral sensory challenge is the imperfect development of speech followed by atypical feeding behavior. Currently, speech therapy is the central therapy used for speech errors, followed by Oral placement therapy, Nonspeech oral motor therapy, and audio digital therapies. However, all oral therapies have advantages and limitations, due amount of time required and nature of the disorder. The present review evaluated the current status of oral therapies and recommended prosthodontic based guidelines based upon the oral sensory-motor pattern associated with ASD subjects.
\end{abstract}

Keywords: Autism Spectrum Disorder (ASD); Oral Placement Therapy; ASD Children

\section{Introduction}

The Current status about the management of oral sensory issues in ASD is centrally focused on Speech Therapy. A speechlanguage pathologist is a therapist who specialized in treating language problems and speech disorders [1]. There are several methods available to motivate and enhancement of productive speech, however there is no classification of the speech therapy that mentioned with any literature, hence the review divides the speech therapy for better-understanding, which are as follows:

- The speech therapy based learning principal: Natural language teaching, and incidental teaching, or pivotal response training. Auditory-motor mapping training technique, and parent telegraphic speech and spoken language technique

- Oral Placement Therapy or Oral motor Therapy: the techniques are Oral motor-and manual motor skills, paltometry, Growth curve model, Talk-Tool ${ }^{\mathrm{TM}}$ Therapy, pressure recording device "PRESLA and the tongue pressure sensor for Biomedical application.
- Nonspeech oral motor treatment. Oral-motor movements but not related to speech.

- Audio-Digital techniques: Video analysis, Music therapy, Computer interactive games, and Mobile applications.

There are a total of 16 articles were evaluated for the oral therapies in ASD (Table 1 and figure 1). The outcome of the single-blind RCT reported that there is no improvement in structural language ability but there is some evidence for the second outcome of parent- reported pragmatic functioning [1]. That means external stimulation from a speech therapist or parent training is necessary for speech and communication. The picture exchange communication system on three ASD children shows that the PECS may the alternative tool for better speech communication, however detailed analysis is necessary to minimize the negative effect of picture [2]. Auditory motor mapping training (AMMT's) multimodal nature facilitates spoken language production by activating shared motor, auditory and visual neural representations of the same vocal/man- 
An Update of Oral Therapies Used for Children and Adolescent of Autism Spectrum Disorder (ASD) and Recommended Prosthodontic Guidelines

ual actions. AMMT is not only improving the spoken language in verbal children but it shows improvement in ASD children who are struggling with significant expressive language and speech production deficits [3]. parent telegraphic speech and spoken language technique for Preschool children with ASD is not discussed in the review, as many studies claimed that telegraphic input may have a negative impact on language development.

\begin{tabular}{|c|c|c|c|}
\hline Therapist & Type of therapy & Method & Results \\
\hline $\begin{array}{l}\text { Adams C } \\
(2012)\end{array}$ & $\begin{array}{l}\text { Randomized control } \\
\text { trial }\end{array}$ & $\begin{array}{c}\text { In a single-blind RCT, there were } 88 \\
\text { children were evaluated for pragmatic as } \\
\text { compared with the structural aspects of } \\
\text { language. }\end{array}$ & $\begin{array}{l}\text { The study findings suggested that there is no } \\
\text { improvement in structural language ability but } \\
\text { there is some evidence for the second outcome } \\
\text { of parent- reported pragmatic functioning. }\end{array}$ \\
\hline $\begin{array}{l}\text { Marjorie M., } \\
\text { et al. (2002) }\end{array}$ & $\begin{array}{l}\text { Picture exchange com- } \\
\text { munication system }\end{array}$ & $\begin{array}{l}\text { Investigate picture exchange communica- } \\
\text { tion on three ASD children }\end{array}$ & $\begin{array}{l}\text { Increases the verbal speech and social commu- } \\
\text { nication. }\end{array}$ \\
\hline $\begin{array}{l}\text { Hayden D } \\
(2006)\end{array}$ & The prompt model & $\begin{array}{l}\text { These model works on four types: Param- } \\
\text { eter prompt, syllabus prompt, complex } \\
\text { prompt, and surface prompt. }\end{array}$ & $\begin{array}{l}\text { PROMPT is comprehensive model to normal- } \\
\text { ized the speech pattern in mixed motor speech } \\
\text { disturbance }\end{array}$ \\
\hline $\begin{array}{l}\text { Cheanusky } \\
\text { KV., et al. } \\
\text { (2017) }\end{array}$ & $\begin{array}{l}\text { Auditory motor map- } \\
\text { ping training }\end{array}$ & $\begin{array}{l}\text { AMMT's multimodal nature facilitates } \\
\text { spoken language production by activating } \\
\text { shared motor, auditory and visual neural } \\
\text { representations of the same vocal/manual } \\
\text { actions. }\end{array}$ & $\begin{array}{l}\text { AMMT is not only improving the spoken lan- } \\
\text { guage in verbal children but it shows improve- } \\
\text { ment in ASD children who are struggling with } \\
\text { significant expressive language and speech } \\
\text { production deficits. }\end{array}$ \\
\hline $\begin{array}{l}\text { Gernsbach- } \\
\text { er MA., et al. } \\
(2008)\end{array}$ & $\begin{array}{l}\text { Oral motor-and manual } \\
\text { motor skills as a part } 1 \\
\text { and home video study } \\
\quad \text { of motor skills }\end{array}$ & $\begin{array}{l}\text { Comparative cohort study of } 10 \text { oral motor } \\
\text { and } 21 \text { manual motor skill for ASD children } \\
\text { and typically developing as a control. The } \\
\text { second part was evaluation of histori- } \\
\text { cal home video to assess the accuracy of } \\
\text { the early oral- and manual-motor data } \\
\text { obtained in the caregivers }\end{array}$ & $\begin{array}{l}\text { The study findings reported that the prominent } \\
\text { associations among early oral- and manual- } \\
\text { motor skills and later speech fluency bear } \\
\text { implications for understanding communication } \\
\text { in autism. }\end{array}$ \\
\hline $\begin{array}{l}\text { Bedford R., } \\
\text { et al. (2016) }\end{array}$ & Growth curve model & $\begin{array}{l}\text { The study design a growth curve models } \\
\text { for expressive and receptive language mea- } \\
\text { sured at 2, 3, } 5 \text { and } 9 \text { years in } 209 \text { autistic } \\
\text { children. Measures of gross motor, visual } \\
\text { reception and autism symptoms were col- } \\
\text { lected at the } 2 \text { year visit. }\end{array}$ & $\begin{array}{l}\text { The study evidence reported that early motor } \\
\text { abilities in young children with ASD have subse- } \\
\text { quent improved development of speech. }\end{array}$ \\
\hline
\end{tabular}

Citation: Sachin Chaware., et al. "An Update of Oral Therapies Used for Children and Adolescent of Autism Spectrum Disorder (ASD) and Recommended Prosthodontic Guidelines". Acta Scientific Dental Sciences 4.12 (2020): 103-110. 
An Update of Oral Therapies Used for Children and Adolescent of Autism Spectrum Disorder (ASD) and Recommended Prosthodontic Guidelines

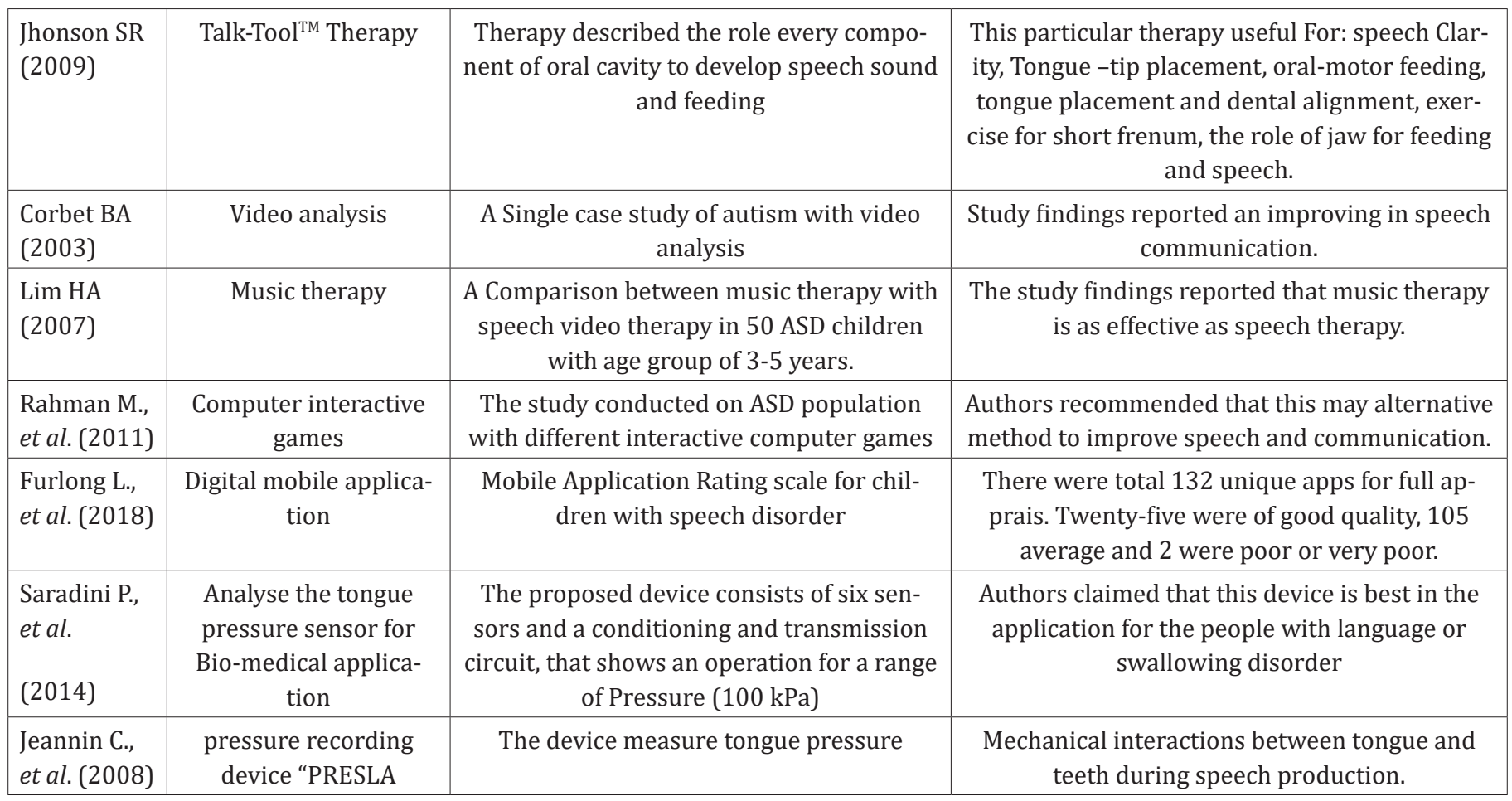

Table 1: Current status of oral therapies.

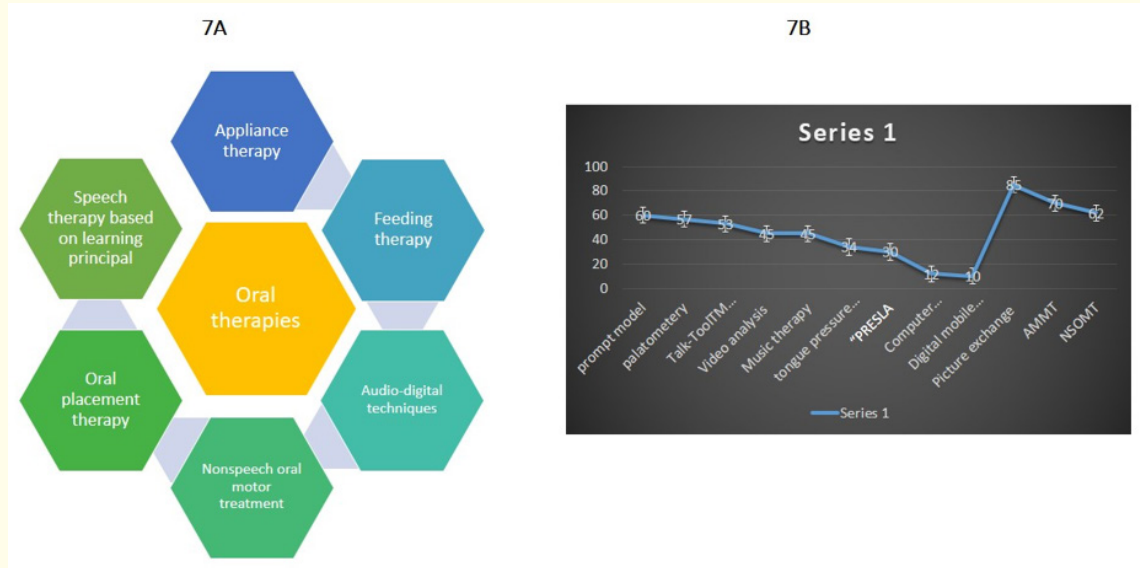

Figure 1: Oral therapies representations.

Oral placement therapy is an interesting part of the speech therapy as it is not involved with stimulation only but it majorly related to oral-speech motor movement that means it mainly concentrates on the component of speech therapy. The significant work was done by Jhonson SR (2009), introduce Talk-Tool therapy [4]. The Talk-Tool therapy highlighted the significant role of oral muscles, jaw position and contact between the tongue and palate during the various positions of speech sound production. The jaw exercises (jaw strengthening is like a pyramid which was called Speech Clarity Pyramid), speech clarity, tongue-tip position, and oral-motor feeding. The paltometry [5] analyse the Computerized visual-auditory feedback tool that provides an online, dynamic display of the 
tongue's contact with the hard palate during speech and swallowing functions. The PROMPT (prompts for restructuring Oral Muscular Phonetic Target), therapy, it is a type of training parameters which allows input into different aspect of speech-motor system of jaw height, facial-labial muscle contraction, tongue height, and advancement, duration of contraction and air stream control of the laryngeal and oral- nasal valve. There are four types prompt. The PROMPT therapy [6] useful for speech-disorder children with moderate to severe mixed phonological errors and oral motor impairment. There are two innovative device: that records the tongue pressure during tongue-palatal contact in speech-disorder children. The palatal sensor appliance [7] for the people with language and swallowing disorder and the PRESLA [8] a device that records the tongue pressure and Mechanical interactions between tongue and teeth during speech production in speech disorder patients. The growth curve model [9] claimed that early motor abilities in young children with ASD have subsequent improved development of speech. The oral motor and manual motor skills on ASD infants and toddler strongly claimed there is a prominent association between early oral-motor and manual skills and later speech fluency [10]. Nonspeech oral motor treatment (NSOMT) [11] are non-speech activities that aim to stimulate or improve speech production and treat specific speech errors. The example of NSOMT are motor exercise such as smiling, pursing, blowing into horns, blowing bubbles, and lip massage to target lip mobility for the production of speech sound involving the lips, such as/p/, /b/, and /m/ (bilabial sound) [11]. However there is challenge the efficiency of NSOMT and the researchers claimed that the further investigation is necessary $[12,13]$. The digital groups show study on Video analysis [14], Music therapy [15], Computer interactive games [16], and mobile applications [17]. All these therapies are useful as an alternative mode of speech production. However, the music therapy reported better outcome and larger effect size.

Recommendation of evidence based prosthodontic guidelines:

The observation of the speech problems, feeding behaviour and other oral sensory issues shows that the speech errors in ASD is related to oral- motor speech disorder which is noted as a Sound-Speech disorder (SSD). The SSD is further related to imperfect motor planning, articulation disorder, phonological disorder, childhood apraxia of speech (CAS) and prosody. The feeding behaviour represented as difficulty in the selection of food, a limited selection of food and interest to a particular food or picky eaters. The feeding and eating behavior depend upon oral tissue sensitivity, either hyposensitivity or hypersensitivity. The oral therapies have a multiple options and the most common central therapy is speech therapy. The speech therapy has a significant role in the improvement in speech and communication. However, the success of speech therapy mainly depends upon the severity of the conditions, the amount of time devoted by speech- language- pathologist and other therapy used for generalized sensory processing. The speech therapy is a long standing procedure, so it will be difficult and frustrated for ASD children and their parents to maintain patience for longer duration and the speech improvement will be seen gradually and dependent upon other sensory issues $[1,18]$. Speech therapy mainly focuses on expressive and receptive speech. The researcher of Oral-placement therapy shows much improvement in oral musculature related to speech, there are several tools that shows improvements in speech but the outcome evidence is low as there is no follow up that shows progress of speech. There are several speech generating device that require further evaluation. The behavioural therapy for food selection also reported the problem of follow up.

There is a need for oral therapy that will work similarly to occupational therapy used for generalized sensory processing in ASD, that works to develop skills for handwriting, fine motor skills, daily living skill and increases awareness. The ideal oral therapy should have combined effect indirect stimulation similar to speech recognition as well as direct intervention in the form of appliance therapy which modulate sensory- motor pattern related to speech and feeding behaviour. The review recommends evidenced-based prosthodontics guidelines as a principal sensorimotor or oral occupational therapist to improve the speech and associated oral sensory difficulties in ASD, on the basis of two observations: Oral neural receptors and prosthodontics role in speech science.

Oral tissues have a special status within the somatosensory system. It is one of the most densely innervated parts of the body in terms of peripheral receptors. Oral tissues are deeply and widely dispersed by a vast number of receptors. The final representation of oral sensation is the primary somatosensory cortex, which is located at a strip extending mediolaterally immediately behind the central sulcus. It comprises Broadman areas 1, 2, 3a and 3b [19]. There are Five MRI studies of oral receptors stimulation and activation of the higher centre of the brain, particularly the areas involved in ASD. Trulsson., et al. (2010) [20] evaluated the activation inferior frontal gyrus (IFG, Broca area: This particular area is associated with social language processing and social attention). Otuska T., et al. (2016) [21], reported the higher activation of the amygdala. ASD shows higher abnormalities in the amygdala and more specifically decrease the volume of the right amygdala. The punctuate mechanical stimulation of Osseointegrated oral implant as a osseoperception $f$ MRI study observed the activation of pri- 
An Update of Oral Therapies Used for Children and Adolescent of Autism Spectrum Disorder (ASD) and Recommended Prosthodontic Guidelines

mary and secondary somatosensory cortex and more precisely the inferior frontal gyrus [22]. The comparative $f$ MRI study of tooth pain representation with manual (hand) pain reported that there is bilateral activation of the primary somatosensory cortex, however, there is unilateral activation of the same in manual pain [23]. The cortical representation of human oral area in the somatosensory cortex reported the classically related to "sensory homunculus" [24]. Eventually, the observation of the $f$ MRI study made it clear that oral tissue representation has a special status in primary and secondary somatosensory cortex. This observation may have signed for further research in ASD, particularly for oral sensory issues.

\begin{tabular}{|c|c|c|c|}
\hline $\begin{array}{l}\text { Author } \\
\text { and year }\end{array}$ & purpose & methods & Results \\
\hline $\begin{array}{l}\text { Trulsson., } \\
\text { et al. } \\
2010\end{array}$ & $\begin{array}{l}\text { Evaluate the brain ac- } \\
\text { tivation in response to } \\
\text { vibrotactile stimula- } \\
\text { tion: A psychophysical } \\
\text { and fMRI study }\end{array}$ & $\begin{array}{l}\text { The study was performed on the first upper } \\
\text { left incisor on Ten healthy, right -handed } \\
\text { male volunteers (aged 18-40) who par- } \\
\text { ticipated in the study. The mechanical } \\
\text { stimulus was delivered by using Mechanical } \\
\text { vibrotactile stimuli via a probe attached to } \\
\text { a piezoelectric bender element stimula- } \\
\text { tor. The mechanical stimulus was delivered } \\
\text { at 20, 50, and } 100 \mathrm{~Hz} \text {. The Psychophysical } \\
\text { measurements were made of their detection } \\
\text { threshold for each of the three frequencies } \\
\text { of mechanical stimulation applied to the } \\
\text { left incisor. The detection threshold was } \\
\text { recorded using a parameter estimation by } \\
\text { sequential testing (PEST) protocol with } \\
\text { LabVIEW controlling the frequency and am- } \\
\text { plitude of the stimulus. } f \text { MRI was performed } \\
\text { on a } 3.0 \text { T echo-planar imaging (EPI) scanner } \\
\text { with quadrature transverse electromagnetic } \\
\text { (TEM) RF coil. }\end{array}$ & 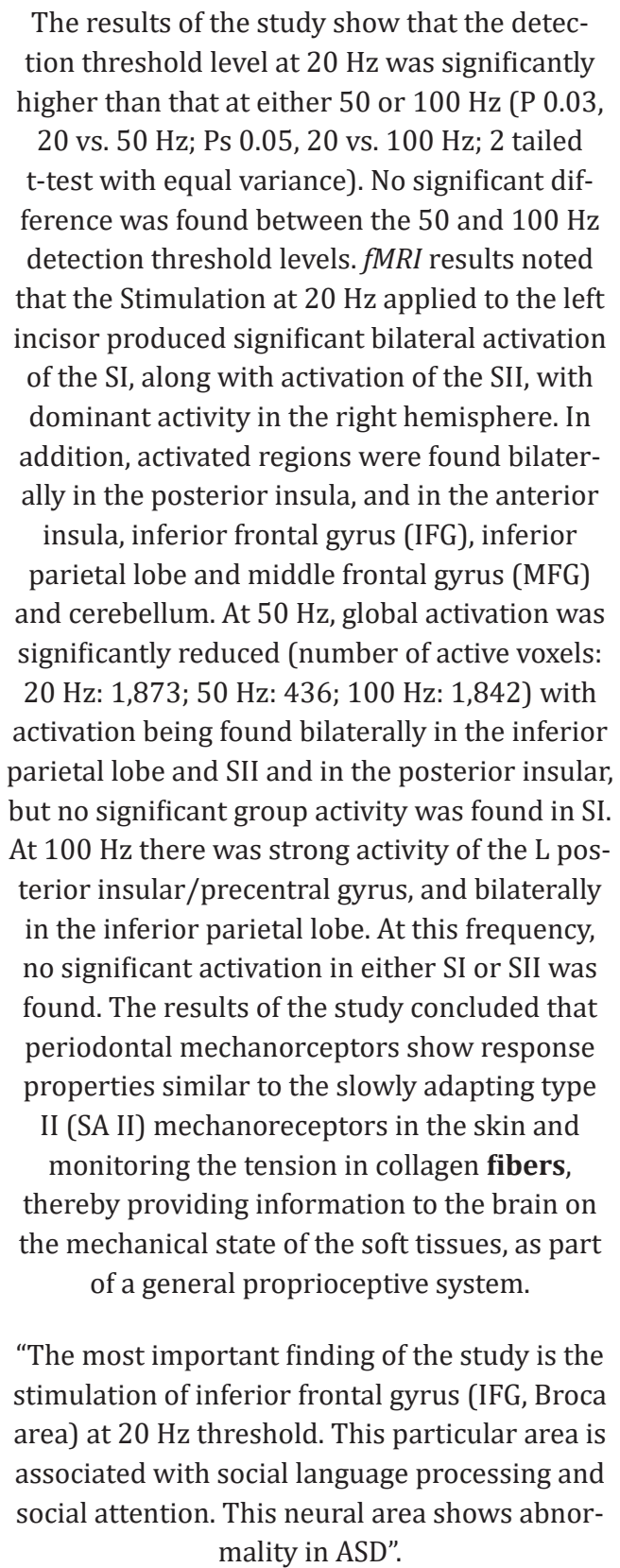 \\
\hline
\end{tabular}

Citation: Sachin Chaware., et al. "An Update of Oral Therapies Used for Children and Adolescent of Autism Spectrum Disorder (ASD) and Recommended Prosthodontic Guidelines". Acta Scientific Dental Sciences 4.12 (2020): 103-110. 


\begin{tabular}{|c|c|c|c|}
\hline $\begin{array}{l}\text { Otuska T., } \\
\text { et al. } \\
2016\end{array}$ & $\begin{array}{l}\text { Experimented oc- } \\
\text { clusal interference on } \\
\text { brain activation dur- } \\
\text { ing gum chewing }\end{array}$ & $\begin{array}{l}\text { The study used occlusally oversized gold } \\
\text { crown that had fabricated by modifying the } \\
\text { gold electroforming system used for the gold } \\
\text { crown, so to create the occlusal interference. } \\
\text { The crown was placed on left mandibular } \\
\text { first molar and three or four points were } \\
\text { marked by using articulating paper and } \\
\text { thickness of marked point was measured. } \\
\text { The tasteless or odorless gum was used for } \\
\text { chewing on the left side. A total } 11 \text { healthy } \\
\text { subjects with no history of psychiatric or } \\
\text { neurological disorders were selected. Each } \\
\text { subject performed the gum-chewing task } \\
\text { with or without the overlay. Each subject } \\
\text { performed a series of four cycles of gum } \\
\text { chewing, each cycle consisting of } 32 \text { s of } \\
\text { chewing and } 32 \text { s of resting. A recovery/ } \\
\text { reset period of } 20-30 \text { min separated the two } \\
\text { chewing series (one with the overlay and } \\
\text { one without the overlay as a control) in each } \\
\text { subject to eliminate the influence of one task } \\
\text { on the other. Each subject quantified their } \\
\text { subjective feeling of discomfort during chew- } \\
\text { ing with a mark, which ranged from } 0 \text { to } 10 \\
\text { (0=no discomfort, } 10=\text { extreme discomfort), } \\
\text { followed by fMRI protocol, which is based } \\
\text { on the blood oxygenation level dependence } \\
\text { (BOLD) effect, which detects signal fluctua- } \\
\text { tions due to changes in the ratio of oxyhemo- } \\
\text { globin to deoxyhemoglobin in the blood in } \\
\text { relation to brain activity }\end{array}$ & $\begin{array}{l}\text { The Statistic shows that the results were signifi- } \\
\text { cant } \mathrm{p}<0.05 \text {. The unpleasant sensation during } \\
\text { gum chewing was much greater in the interfer- } \\
\text { ence group than the control group ( }<<0.01 \text { ). } \\
\text { However, fMRI findings were more significant } \\
\text { it shows the higher activation in the amygdala } \\
\text { ( } \mathrm{p}<0.001 \text { ), anterior cingulate cortex ( } \mathrm{p}<0.001 \text { ), } \\
\text { prefrontal area ( } \mathrm{p}<0.05 \text { ), and hypothalamus } \\
\text { ( } \mathrm{p}<0.05 \text { ). The results of the study concluded } \\
\text { that stimulation from occlusal interference is } \\
\text { rapidly relayed to the brain and related to acti- } \\
\text { vation of emotions of discomfort. } \\
\text { The interesting finding of the study is the higher } \\
\text { activation of the amygdala. The amygdala is } \\
\text { a processing center that receives incoming } \\
\text { messages from our senses. It is highly involved } \\
\text { in different emotional responses. ASD shows } \\
\text { higher abnormalities in the amygdala and } \\
\text { more specifically decrease volume of the right } \\
\text { amygdala }\end{array}$ \\
\hline $\begin{array}{l}\text { Habare- } \\
\text { hallage P., } \\
\text { et al. } 2012\end{array}$ & $\begin{array}{l}\text { Evaluate the Brain } \\
\text { plasticity and corti- } \\
\text { cal correlates of } \\
\text { osseoperception } \\
\text { revealed by punctate } \\
\text { mechanical stimula- } \\
\text { tion of osseointe- } \\
\text { grated oral implants } \\
\text { during fMRI }\end{array}$ & $\begin{array}{l}\text { A cross-sectional observational study with } \\
9 \text { volunteering patients and } 10 \text { age-matched } \\
\text { controls. For each patient, functional mag- } \\
\text { netic resonance imaging (fRMI) recordings } \\
\text { were made during punctate mechanical } \\
\text { stimulation of either teeth or osseointegrated } \\
\text { implants in the maxillary incisor area. }\end{array}$ & $\begin{array}{l}\text { The results of the study demonstrate that punc- } \\
\text { tate mechanical stimulation of oral implants } \\
\text { activates both primary and secondary cortical } \\
\text { somatosensory areas. This cortical activation } \\
\text { may represent the underlying mechanism of } \\
\text { osseoperception. However, the activation of } \\
\text { inferior frontal gyrus was the main observation. }\end{array}$ \\
\hline $\begin{array}{l}\text { Jantsch } \\
\text { HH., et al. }\end{array}$ & $\begin{array}{l}\text { Investigated the Corti- } \\
\text { cal representation of } \\
\text { experimental tooth } \\
\text { pain in humans. }\end{array}$ & $\begin{array}{l}\text { It is an fMRI experiment that compares the } \\
\text { cortical representation of tooth pain was } \\
\text { compared with that of painful mechanical } \\
\text { stimulation to the hand }\end{array}$ & $\begin{array}{l}\text { The results of the study shows that there is } \\
\text { bilateral activation of primary somatosen- } \\
\text { sory cortex (S1) in case of tooth pain wherein } \\
\text { mechanical stimulation of hand pain there is a } \\
\text { unilateral activation of S1. tooth pain activates a } \\
\text { cortical network that is in several respects dif- } \\
\text { ferent from that activated by painful mechanical } \\
\text { stimulation of the hand. }\end{array}$ \\
\hline $\begin{array}{l}\text { Miyamoto } \\
\text { JJ., et al. } \\
2006\end{array}$ & $\begin{array}{l}\text { Evaluate the cortical } \\
\text { representation of hu- } \\
\text { man oral area in the } \\
\text { somatosensory cortex } \\
\text { by using fMRI }\end{array}$ & $\begin{array}{l}\text { The study was conducted on Fourteen } \\
\text { healthy volunteers (eight males and six } \\
\text { females, mean age = } 32.6 \text { years, range 24--56 } \\
\text { years) participated in this study. Thirteen } \\
\text { subjects were right-handed, and one was left- } \\
\text { handed. Subjects were stimulated at three } \\
\text { areas on the right side of the oral area: the } \\
\text { lower lip, the tongue, and the upper central } \\
\text { incisor tooth. The lower lip and tongue were } \\
\text { stimulated by using the stick with a piece of } \\
\text { Velcro at its tip. The right upper incisor tooth } \\
\text { was also stimulated using the stick with a } \\
\text { grooved rubber tip. }\end{array}$ & $\begin{array}{l}\text { fMRI observation of cortical representations of } \\
\text { the oral area shows that the representation of } \\
\text { teeth was located significantly superior to that } \\
\text { of the tongue and inferior to that of the lip In } \\
\text { the rostral portion of the Postcental gyrus. This } \\
\text { findings classically related to "sensory homun- } \\
\text { culus". the findings of the study further stated } \\
\text { that the input from oral structures converges } \\
\text { hierarchically across the primary somatosen- } \\
\text { sory cortex }\end{array}$ \\
\hline
\end{tabular}

Table 2: Studies representation of oral tissue to higher centre of the brain. 
An Update of Oral Therapies Used for Children and Adolescent of Autism Spectrum Disorder (ASD) and Recommended Prosthodontic Guidelines

Prosthodontics is a recognized specialty of dentistry, that deals with the replacement and restoration of missing oral tissue. Prosthodontics has precise knowledge of speech science and their application in a prosthetic appliance. The advancement of computerization in prosthetic dentistry such as CAD- CAM and 3- Printing based prosthesis evaluate better tissue perception. The palatal plate recontouring and maxillary incisor positioning in phonetic improvement was already proved. Apart from the speech therapy, the prosthodontics can have a significant impact on speech development and feeding behaviour, as precise manipulation of the oral musculature and articulation of the speech component can be well managed by prosthetic based appliance therapy than other oral therapies. The evident role of prosthodontics in speech improvement and feeding pattern in the patients with a functional articulation disorder, such as the Patient with cleft lip and palate, oral motor disorder, down syndrome, and cerebral palsy has been already established $[25,26]$. The together role of prosthodontics and speech pathologist has been already reported with the rehabilitation of cleft lip and palate patient $[27,28]$. The oral placement therapy, NSOMMT, appliance therapy and oral muscular therapy such as chewing of the soft tube reported the lack of specificity, as the application is used the generalised concept. The speech production requires specific contact between the tongue and hard palate as well as contact between the lower lip to upper incisor and contact between the lips. The air volume during speech production, the balance between the lip, teeth, cheek, and palate during speech production and the specific distance travelled by tongue to palate during the production of $/ \mathrm{t} / \mathrm{,} / \mathrm{d} / \mathrm{s} / \mathrm{and} / \mathrm{n} /$ are the best judge and managed by prosthodontics therapy. Similarly type of oral sensitivity during feeding and swallowing can a certain extent impact by prosthodontics. Eventually, the prosthodontics can be a principal oral sensorimotor or oral occupational therapist can be the part of the team along with speech therapist and occupational therapist to improve the outcome of speech and feeding problem in ASD children and adolescent of ASD, particularly minimally verbal ASD children, high functioning autism and asparagus syndrome.

\section{Conclusion and Limitations}

The review evaluated the shortcomings and current status of oral therapies and suggestions regarding the need for advanced therapy. Hence, the evidenced- based guidelines were discussed. Eventually, the dynamic role of dental speciality in the stimulation of the oral tissue in various phase of the prosthetic application and may have an immense impact on improvement in speech and feeding of ASD children and adolescents. Thus, the main recommendation of the review to gain the attention of dental speciality as a principal oral sensorimotor or oral occupational therapist to form stable prosthetic based applications for improvement in speech and feeding problems in ASD children and adolescents. There is a lack of specificity in terms of evidence as speech assessment reported generalized speech errors with ASD but did not specify which component of speech is majorly involved. The articulation errors did not specify interference of articulation of oral component. The phonological errors and prosody showed different appearances in various ASD groups. The oral therapies showed a lack of sensitivity at the outcome level. Apart from speech learning principal, there are other therapies that have a less study population and does not focus on sensory issues at outcome level.

\section{Bibliography}

1. Adams C., et al. "The social communication intervention project: a randomized controlled trial of the effectivenss of speech and language therapy for school-age children who have pragmatic and social communication problems with or without autism spectrum disorder". International Journal of Language and Communication Disorders 47.3 (2012): 233-244.

2. Charlop-Christy MH., et al. "Using the picture exchange communication systems (PICS) with children with autism assessment of PICS Acquisition speech social -communication behaviour and problem behaviour". Journal of Applied Behavior Analysis 35.3 (2002): 213-231.

3. Cheunsky KV., et al. "Auditory-Motor Mapping Training in a More Verbal Child with Autism". Frontiers in Human Neuroscience 426 (2017): 1-9.

4. Rosenfeld-Johnson S. "Effects of oral-motor therapy for tongue thrust and speech production". Poster session presented at the annual meeting of the American Speech-Language-Hearing Association, Chicago, IL (2008).

5. Fletcher S. Palatometry principles and practice. Session presented at the annual meeting of the American Speech-Language-Hearing Association, Chicago, IL (2008).

6. Hayden D. "The PROMPT model: Use and application for children with mixed phonological- motor impairment". Advanced in Speech-Language Pathology 8.3 (2009): 265-281.

7. Saradini E., et al. "Analysis of tongue pressure sensor for biomedical application". IEEE International Symposium on Medical (2014).

8. Jeannin C., et al. "PRESLA: An original device to measure the mechanical interaction between tongue and teeth or palate during speech production". 8th international seminar on speech production (2008): 49-52. 
9. Bedford R., et al. "Early Gross Motor Skills Predict the Subsequent Development of Language in Children with Autism Spectrum Disorder". Autism Research 9 (2016): 993-1001.

10. Gernsbacher MA., et al. "Infant and toddler oral and manual motor skills predict later speech fluency in autism". Journal of Child Psychology and Psychiatry 49.1 (2008): 43-50.

11. McCauley RJ., et al. "Evidenced -based systemetic review: effects of nonspeech oral motor exercises on speech". American Journal of Speech-Language Pathology (2009).

12. Forrest $\mathrm{K}$ and Luzzini J. "A comparison of oral motor and production training for children with speech sound disorders". Seminars in Speech and Language 29.4 (2008): 304-311.

13. Lof GL and Watson MM. "A Nationwide Survey of Nonspeech Oral Motor Exercise Use: Implications for Evidence-Based Practice". Language, Speech, and Hearing Services in Schools 39 (2008): 392-407.

14. Corbett BA. "Video Modeling: A Window into the World of Autism". The Behavior Analyst Today 4.3 (2003): 367-377.

15. Lim HA. "The Effect of "Developmental Speech-Language Training through Music" on Speech Production in Children with Autism Spectrum Disorders". Journal of Music Therapy 47.1 (2010): 2-26.

16. Raheman MD., et al. "Speech development of autistic children by interactive computer games". Interactive Technology and Smart Education 8.4 (2011): 208-223.

17. Furlong L., et al. "Mobile apps for treatment of speech disorders in children: An evidence-based analysis of quality and efficacy. An evidence-based analysis of quality and efficacy". PLoS ONE 13.8 (2020): e0201513.

18. Reason children don't make progress with speech language therapy.

19. Haggard P and Boer LD. "Oral Somatosensory Awareness". Neuroscience and Biobehavioral Reviews 47 (2014): 469-484.

20. Trullson., et al. "Brain activation in response to vibrotactile tooth stimulation: A psychphysical and fMRI study". Journal of Neurophysiology 104.4 (2010): 2257-2265.

21. Otuska T., et al. "Experimental occlusal interference on brain activation during gum chewing". Biomedical Research 28.1 (2017): 453-458.
22. Habre-Hallage P., et al. "Brain plasticity and cortical correlates of osseoperceptation revealed by punctuate mechanical stimulation of osseointegrated oral implants during fMRI". European Journal of Oral Implantology 5.2 (2012): 175-190.

23. Jatisch HHF, et al. "Cortical representation of experimental tooth pain in human's pain". Pain 118.3 (2005): 390-399.

24. Miyamoto JJ., et al. "The representations of the human oral areas in the primary somatosensory cortex: a functional MRI study". Cerebral Cortex 16.6 (2006): 669-675.

25. Anya E., et al. "Prosthodontic rehabilitation alternative of patient with cleft Lip and Palate (CLP): Two Case Report". International Journal of Dentistry (2009).

26. Alqahtani NM., et al. "Prosthodontic rehabilitation for a patient with Down Syndrome: A clinical Report". Journal of Prosthodentics 27.8 (2018): 681-687.

27. Dhanlaksmi MR., et al. "Prosthodontics management in conjunction with speech therapy in a cleft lip and palate: A review and case report". Journal of International Oral Health 7 (2015): 106-111.

28. Ribeiro da Silva T., et al. "Density - speech integration the importance of interdisciplinary teams formation". Revista CEFAC 16.2 (2014): 598-603.

\section{Assets from publication with us}

- Prompt Acknowledgement after receiving the article

- Thorough Double blinded peer review

- Rapid Publication

- Issue of Publication Certificate

- High visibility of your Published work

Website: www.actascientific.com/

Submit Article: www.actascientific.com/submission.php

Email us: editor@actascientific.com

Contact us: +919182824667 